\title{
TINJAUAN HUKUM ISLAM TENTANG PELAKSANAAN PINJAMAN DENGAN JAMINAN EMAS PADA PEMBIAYAAN MULIA DI PEGADAIAN SYARIAH
}

\author{
Hidayatina \\ Jurusan Syariah STAIN Malikussaleh Lhokseumawe \\ Jl. Medan Banda Aceh Km. 275, No. Buket Rate-Alue Awe, Lhokseumawe \\ e-mail: hidayatina@ymail.com
}

\begin{abstract}
This research aimed at figuring out the regulations of Islamic laws in dealing with loans and gold as warranty on Mulia Financing in Islamic pawnshop. To achieve the desired aim, this study employed normative study by applying qualitative approach. Furthermore, conceptual approach which was dealing with multi-agreements in Islamic law was used to figure out the implementation loan using gold as warranty on Mulia Financing in Islamic pawnshop according to Islamic laws. The data of the research were the secondary ones which were obtained from books, internet resources and previous relevant studies and collected through library research. The data were analyzed by means of normative analyisis and study based the available data. The findings showed that the implementations were not suitable with Islamic laws due to the absence of the requirement for the objects of loan. Furthermore, multi-agreement practices which are probibited in Islam also took place.
\end{abstract}

Kata kunci: hukum Islam, pinjaman, jaminan emas, pembiayaan MULIA

\section{PENDAHULUAN}

Hukum asal mu'amalah berdasarkan $\mathcal{H}$ ilmu ushul figh menyatakan bahwa "segala sesuatunya diperbolehkan, kecuali ada larangan dalam Alquran atau asSunnah". Yang perlu dilakukan dalam hal muamalah adalah mengidentifikasikan hal-hal yang dilarang (haram), kemudian menghindarinya. Selain hal-hal yang diharamkan tersebut, kita boleh menciptakan, menambah, mengembangkan, dan mempergunakan daya kreativitas (ijtihad) dalam bidang muamalah untuk kemajuan peradaban manusia.

Di sinilah letak fleksibilitas syari'at Islam. Pada umumnya, syari'at Islam dalam bidang muamalah hanya memberikan petunjuk-petunjuk dan prinsip-prinsip yang sifatnya umum dan mendasar.
Hal-hal yang lebih rinci, detail dan teknis tidak diatur, tetapi diserahkan kepada manusia melalui proses ijtihad. Dengan demikian, bidang muamalah ini akan selalu berkembang dan mengakomodasi perubahan-perubahan yang terjadi di berbagai bidang di tengah-tengah masyarakat serta dapat diterapkan di bidang apa saja, seperti jual beli, sewa-menyewa, gadai, perbankan, dan kegiatan-kegiatan perekonomian lainnya (Adiwarman Karim, 2004: 9).

Salah satu bentuk akad muamalah yang dibolehkan dalam hukum Islam untuk mengakomodir keinginan dan kebutuhan masyarakat adalah akad murabahah yang merupakan akad jual beli, penjual menyebutkan harga pembelian barang kepada pembeli, kemudian ia 
mensyaratkan atas laba dalam jumlah tertentu (Warkum Sumitro, 2002: 117). Kemudian bentuk akad lain yang dibolehkan dalam hukum Islam yaitu gadai yang dikenal dengan istilah al-rahn, yang merupakan jaminan kebendaan yang merupakan suatu jenis perjanjian untuk menahan suatu barang sebagai tanggungan utang. Hal itu, berdasarkan firman Allah Swt yang berbunyi:

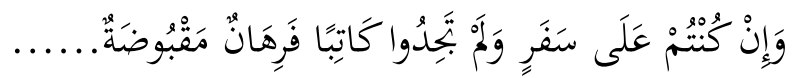

Jika kamu dalam perjalanan (dan bermuamalah tidak secara tunai) sedang kamu tidak memperoleh seorang penulis, maka hendaklah ada barang tanggungan yang dipegang (oleh yang berpiutang). (Q.S. al-Baqarah [2]: 283)

Penerapan muamalah dalam masyarakat bersifat fleksibel, di mana sejalan dengan perkembangan zaman yang diiringi dengan kebutuhan dan keinginan masyarakat yang semakin kompleks. Pegadaian syariah turut hadir memberikan kontribusi dengan salah satu produknya, yaitu pembiayaan emas MULIA, (Murabahah Logam Mulia Untuk Investasi Abadi), yaitu penjualan logam mulia oleh pegadaian kepada masyarakat secara tunai atau angsuran dengan agunan jangka waktu fleksibel.

Namun, berdasarkan hasil penelitian skripsi yang dilakukan oleh Nurhasita (Nurhasita, Skripsi, 2015 t.h.) di samping pembiayaan MULIA yang diberikan oleh pegadaian syariah kepada nasabahnya, pihak pegadaian syariah juga memperbolehkan nasabah tersebut untuk mengajukan pinjaman kembali atau mengambil produk pegadaian syariah yang lain dengan menjaminkan kembali emas yang sedang menjadi objek jaminan pada pembiayaan MULIA.
Dalam setiap interaksi antar manusia pasti dapat menimbulkan permasalahan dan ketidaksepahaman. Di samping kemudahan dalam bermuamalah tersebut, juga dibebani tanggung jawab untuk memberikan rasa keadilan bagi semua pihak yang menjalankannya. Dengan kata lain dalam kegiatan bermuamalah tersebut harus menggunakan ketentuan-ketentuan yang berlaku di bidang hukum Islam. Ketentuan-ketentuan hukum Islam yang mengatur mengenai kegiatan antar manusia tersebut dikenal dengan prinsip-prinsip syariah. Berangkat dari pendahuluan tersebut, penulis tertarik mengkaji lebih jauh bagaimana sebenarnya ketentuan hukum Islam terhadap pelaksanaan pinjaman dengan menjaminkan emas yang belum lunas pembiayaannya, dalam bentuk penelitian ilmiah dengan judul:

"Tinjauan Hukum Islam tentang Pelaksanaan Pinjaman dengan Jaminan Emas pada Pembiayaan MULIA di Pegadaian Syariah".

Berangkat dari permasalahan yang dikemukakan di atas, maka masalah pokok yang menjadi rumusan masalah dalam penelitian ini adalah bagaimanakah ketentuan hukum Islam tentang pinjaman dengan jaminan emas pada pembiayaan MULIA di Pegadaian syariah?

\section{METODE PENELITIAN}

1. Jenis penelitian, penelitian ini adalah penelitian normatif menggunakan analisis kualitatif yakni dengan menjelaskan data-data yang ada dengan kata-kata atau pernyataan bukan dengan angkaangka. Dan menggunakan pendekatan konsep (conceptual approach) tentang: ketentuan akad berganda dalam hukum Islam yang bertujuan untuk mengetahui bagaimana pelaksaan pinjaman dengan jaminan emas MULIA pada pada 
pegadaian syariah menurut hukum Islam.

2. Jenis data, data dalam penelitian ini adalah data sekunder, yaitu data dari buku-buku, media internet dan penelitian terdahulu yang mengkaji tentang pelaksanaan pembiayaan MULIA di pegadaian syariah.

3. Teknik pengumpulan data, yaitu melalui library research yaitu buku-buku, media internet, dan penelitian terdahulu.

4. Teknik analisis data, yaitu dengan menggunakan data kualitatif dengan metode analisis dan kajian normatif berdasarkan sumber-sumber tertulis yang ada.

\section{KETENTUAN AKAD BERGANDA (MULTI AKAD) DALAM HUKUM ISLAM}

Ketentuan Akad Berganda (Multi Akad) dalam Hukum Islam (Hasanudin, 2009: 3)

\section{Pengertian, Jenis, dan Model Multi Akad}

Multi dalam bahasa Indonesia berarti (1) banyak; lebih dari satu; lebih dari dua; (2) berlipat ganda (Tim Penyusun Kamus Besar Bahasa Indonesia, 1996: 671). Dengan demikian, multi akad dalam bahasa Indonesia berarti akad berganda atau akad yang banyak, lebih dari satu.

Sedangkan menurut istilah fikih, kata multi akad merupakan terjemahan dari kata Arab yaitu al-'uqud almurakkabah yang berarti akad ganda (rangkap). Al-'uqud al-murakkabah terdiri dari dua kata al-'uqud (bentuk jamak dari 'aqd) dan al-murakkabah. Kata 'aqd secara etimologi artinya mengokohkan, meratifikasi dan mengadakan perjanjian (Ahmad Warson Munawwir, 1997: 953). Sedangkan secara terminologi 'aqd berarti mengadakan perjanjian atau ikatan yang mengakibatkan munculnya kewajiban (Louis Ma'luf, 1986: 519).

Kata al-murakkabah (murakkab) secara etimologi berarti al-jam'u (mashdar), yang berarti pengumpulan atau penghimpunan (Ahmad Warson Munawwir, 1997: 209). Kata murakkab sendiri berasal dari kata "rakkaba-yurakkibu-tarkiban" yang mengandung arti meletakkan sesuatu pada sesuatu yang lain sehingga menumpuk, ada yang di atas dan ada yang di bawah. Sedangkan murakkab menurut pengertian para ulama fikih adalah sebagai berikut:

1. Himpunan beberapa hal sehingga disebut dengan satu nama. Seseorang menjadikan beberapa hal menjadi satu hal (satu nama) dikatakan sebagai melakukan penggabungan (tarkib).

2. Sesuatu yang dibuat dari dua atau beberapa bagian, sebagai kebalikan dari sesuatu yang sederhana (tunggal/basith) yang tidak memiliki bagian-bagian.

3. Meletakkan sesuatu di atas sesuatu lain atau menggabungkan sesuatu dengan yang lainnya.

\section{Macam-macam Multi Akad}

Al-'Imrani membagi multi akad dalam lima macam (Ahmad Warson Munawwir, 1997: 7).

1. Akad Bergantung/Akad Bersyarat (al'Uqud al-Mutaqabilah)

Al-Mutaqabilah menurut bahasa berarti berhadapan. Sesuatu dikatakan berhadapan jika keduanya saling menghadap kepada yang lain. Sedangkan yang dimaksud dengan al-'uqud almutaqabilah adalah multi akad dalam bentuk akad kedua merespon akad pertama, di mana kesempurnaan akad 
pertama bergantung pada sempurnanya akad kedua melalui proses timbal balik. Dengan kata lain, akad satu bergantung dengan akad lainnya.

2. Akad Terkumpul (al-'Uqudal-Mujtami'ah)

Al-'uqud al-mujtami'ah adalah multi akad yang terhimpun dalam satu akad. Dua atau lebih akad terhimpun menjadi satu akad. Seperti contoh "Saya jual rumah ini kepadamu dan saya sewakan rumah yang lain kepadamu selama satu bulan dengan harga lima ratus ribu".

3. Akad berlawanan (al-'Uqud al-Mutanaqidhah wa al-Mutadhadah wa al-Mutanafiyah)

Ketiga istilah al-mutanaqidhah, almutadhadah, al-mutanafiyah memiliki kesamaan bahwa ketiganya mengandung maksud adanya perbedaan. Tetapi ketiga istilah ini mengandung implikasi yang berbeda. Mutanaqidhah mengandung arti berlawanan, seperti pada contoh seseorang berkata sesuatu lalu berkata sesuatu lagi yang berlawanan dengan yang pertama. Seseorang mengatakan bahwa sesuatu benar, lalu berkata lagi sesuatu itu salah. Perkataan orang ini disebut mutanaqidhah, saling berlawanan (Hasanudin, 2009: 3). Dikatakan mutanaqidhah karena antara satu dengan yang lainnya tidak saling mendukung, melainkan mematahkan.

4. Akad berbeda (al-'Uqud al-Mukhtalifah)

Maksudnya adalah terhimpunnya dua akad atau lebih yang memiliki perbedaan semua akibat hukum di antara kedua akad itu atau sebagiannya. Seperti perbedaan akibat hukum dalam akad jual beli dan sewa, dalam akad sewa diharuskan ada ketentuan waktu, sedangkan dalam jual beli sebaliknya.

5. Akad sejenis (al-'Uqud al-Mutajanisah)

Al-uqud al-murakkabah al-mutajanisah adalah akad-akad yang mungkin dihimpun dalam satu akad, dengan tidak mempengaruhi di dalam hukum dan akibat hukumnya. Multi akad jenis ini dapat terdiri dari satu jenis akad seperti akad jual beli dan akad jual beli, atau dari beberapa jenis seperti akad jual beli dan sewa menyewa. Multi akad jenis ini dapat pula terbentuk dari dua akad yang memiliki hukum yang sama atau berbeda.

Dari lima macam akad itu, dua macam yang pertama; al-'uqud almutaqabilah, al-'uqud al-mujtami'ah, adalah multi akad yang umum dipakai.

\section{Hukum Multi Akad}

Mengenai status hukum multi akad, ulama berbeda pendapat terutama berkaitan dengan hukum asalnya. Perbedaan ini menyangkut apakah multi akad sah dan diperbolehkan atau batal dan dilarang untuk dipraktikkan. Mengenai hal ini ulama berada dalam dua pendapat tersebut; membolehkan dan melarang.

Mayoritas ulama Hanafiyah, sebagian pendapat ulama Malikiyah, ulama Syafi'iyah, dan Hanbali berpendapat bahwa hukum multi akad sah dan diperbolehkan menurut syariat Islam. Bagi yang membolehkan beralasan bahwa hukum asal dari akad adalah boleh dan sah, tidak diharamkan dan dibatalkan selama tidak ada dalil hukum yang mengharamkan atau membatalkannya (Hasanudin, 2009: 3).

Menurut Ibnu Taimiyah, hukum asal dari segala muamalah di dunia adalah boleh kecuali yang diharamkan Allah dan Rasul-Nya, tiada yang haram kecuali yang diharamkan Allah, dan tidak ada agama kecuali yang disyariatkan. 


\section{Batasan dan Standar Multi Akad}

Para ulama yang membolehkan praktik multi akad bukan berarti membolehkan secara bebas, tetapi ada batasan-batasan yang tidak boleh dilewati. Karena batasan ini akan menyebabkan multi akad menjadi dilarang. Di kalangan ulama, batasanbatasan ini ada yang disepakati dan diperselisihkan. Secara umum, batasan yang disepakati oleh para ulama adalah sebagai berikut:

\section{Multi Akad Dilarang karena Nash Agama}

Dalam hadis, Nabi secara jelas menyatakan tiga bentuk multi akad yang dilarang, yaitu multi akad dalam jual beli (ba'i) dan pinjaman, dua akad jual beli dalam satu akad jual beli dan dua transaksi dalam satu transaksi Dalam sebuah hadis disebutkan.

$$
\text { هَى رسول الله صلى الله عليه و سلم عن بيع وسلف }
$$

Dari Abu Hurairah Ra. dia berkata: Rasulullah Saw. melarang jual beli dan pinjaman. (HR Ahmad)

Ibnu Qayyim berpendapat bahwa Nabi melarang multi akad antara akad salaf (memberi pinjaman/qardh) dan jual beli, meskipun kedua akad itu jika berlaku sendiri-sendiri hukumnya boleh. Larangan menghimpun salaf dan jual beli dalam satu akad untuk menghindari terjurumus kepada riba yang diharamkan. Hal itu terjadi karena seseorang meminjamkan (qardh) seribu, lalu menjual barang yang bernilai delapan ratus dengan harga seribu. Dia seolah memberi seribu dan barang seharga delapan ratus agar mendapatkan bayaran dua ribu. Di sini ia memperoleh kelebihan dua ratus.
Selain multi akad antara salaf dan jual beli yang diharamkan, ulama juga sepakat melarang multi akad antara berbagai jual beli dan qardh dalam satu transaksi. Semua akad yang mengandung unsur jual beli dilarang untuk dihimpun dengan qardh dalam satu transaksi, seperti antara ijarah dan qardh, salam dan qardh, sharf dan qardh, dan sebagainya.

\section{Multi Akad sebagai Hilah Ribawi}

Multi akad yang menjadi hilah ribawi dapat terjadi melalui kesepakatan jual beli 'inah atau sebaliknya dan hilah riba fadhl.

1. Al-'Inah

Contoh 'inah yang dilarang adalah menjual sesuatu dengan harga seratus secara cicil dengan syarat pembeli harus menjualnya kembali kepada penjual dengan harga delapan puluh secara tunai. Pada transaksi ini seolah ada dua akad jual beli, padahal nyatanya merupakan hilah riba dalam pinjaman (qardh), karena objek akad semu dan tidak faktual dalam akad ini. Sehingga tujuan dan manfaat dari jual beli yang ditentukan syariat tidak ditemukan dalam transaksi ini.

Ibn al-Qayyim menjelaskan bahwa agama menetapkan seseorang yang memberikan qardh (pinjaman) agar tidak berharap dananya kembali kecuali sejumlah qardh yang diberikan, dan dilarang menetapkan tambahan atas qardh baik dengan hilah atau lainnya. Demikian pula dengan jual beli disyariatkan bagi orang yang mengharapkan memberikan kepemilikan barang dan mendapatkan harganya, dan dilarang bagi yang bertujuan riba fadhl atau riba nasai', bukan bertujuan 
pada harga dan barang (Hasanudin, 2009: 21).

Demikian pula dengan transaksi kebalikan "inah juga diharamkan. Seperti seseorang menjual sesuatu dengan harga delapan puluh tunai dengan syarat ia membelinya kembali dengan harga seratus tidak tunai. Transaksi seperti ini telah menyebabkan adanya riba (Hasanudin, 2009: 3).

2. Hilah riba fadhl

Hal ini terjadi apabila seseorang menjual sejumlah (misalnya $2 \mathrm{~kg}$ beras) harta ribawi dengan sejumlah harga (misalnya Rp. 10.000) dengan syarat bahwa ia dengan harga yang sama (Rp. 10.000) harus membeli dari pembeli tadi sejumlah harta ribawi sejenis yang kadarnya lebih banyak (misalnya $3 \mathrm{~kg}$ ) atau lebih sedikit (misalnya $1 \mathrm{~kg}$ ). Transaksi seperti ini adalah model hilah riba fadhl yang diharamkan.

3. Multi akad menyebabkan jatuh ke riba Setiap multi akad yang mengantarkan pada yang haram, seperti riba, hukumnya haram, meskipun akad-akad yang membangunnya adalah boleh. Penghimpunan beberapa akad yang hukum asalnya boleh namun membawanya kepada yang dilarang menyebabkan hukumnya menjadi dilarang.

4. Multi akad antara akad salaf dan jual beli

Seperti dijelaskan sebelumnya, bahwa Nabi melarang multi akad antara akad jual dan salaf. Larangan ini disebabkan karena upaya mencegah (sadd adz-dzari'ah) jatuh kepada yang diharamkan berupa transaksi ribawi.

Jumhur ulama melarang praktik multi akad ini, yakni terjadinya penghimpunan akad jual beli (mu'awadhah) dengan pinjaman (qardh) apabila dipersyaratkan. Jika transaksi multi akad ini terjadi secara tidak disengaja diperbolehkan karena tidak adanya rencana untuk melakukan qardh yang mengandung riba.

5. Multi akad antara qardh dan hibah kepada pemberi pinjaman (muqridh)

Ulama sepakat mengharamkan alqardh yang dibarengi dengan persyaratan imbalan lebih, berupa hibah atau lainnya. Seperti contoh, seseorang meminjamkan (memberikan utang) suatu harta kepada orang lain, dengan syarat ia menempati rumah penerima pinjaman (muqtaridh), atau muqtaridh memberi hadiah kepada pemberi pinjaman, atau memberi tambahan kuantitas atau kualitas objek al-qardh saat mengembalikan. Transaksi seperti ini dilarang karena mengandung unsur riba. Namun apabila transaksi pinjam meminjam ini kemudian disertai hadiah atau kelebihan, tetapi dilakukan sendiri secara sukarela oleh orang yang diberi pinjaman, tanpa ada syarat dan kesepakatan sebelumnya hukumnya halal, karena tidak mengandung unsur riba di dalamnya.

6. Multi akad terdiri dari akad-akad yang akibat hukumnya saling bertolak belakang atau berlawanan

Kalangan ulama Malikiyah mengharamkan multi akad antara akad-akad yang berbeda ketentuan hukumnya dan/atau akibat hukumnya saling berlawanan atau bertolak belakang. Larangan ini didasari atas larangan Nabi menggabungkan akad salaf dan jual beli. Dua akad ini mengandung hukum yang berbeda. Jual beli adalah kegiatan muamalah yang kental dengan nuansa dan upaya perhitungan untung-rugi, sedangkan salaf adalah kegiatan sosial yang mengedepankan aspek persaudaraan 
dan kasih sayang serta tujuan mulia. Karena itu, ulama Malikiyah melarang multi akad dari akad-akad yang berbeda hukumnya, seperti antara jual beli dengan ju'alah, sharf, musaqah, syirkah, qiradh, atau nikah.

Meski demikian, sebagian ulama Malikiyah dan mayoritas ulama nonMalikiyah membolehkan multi akad jenis ini. Mereka beralasan perbedaan hukum dua akad tidak menyebabkan hilangnya keabsahan akad. Dari dua pendapat ini, pendapat yang membolehkan multi akad jenis ini adalah pendapat yang unggul (Hasanudin, 2009: 23). Larangan multi akad ini karena penghimpunan dua akad yang berbeda dalam syarat dan hukum menyebabkan tidak sinkronnya kewajiban dan hasil. Hal ini terjadi karena dua akad untuk satu objek dan satu waktu, sementara hukumnya berbeda. Sebagai contoh tergabungnya antara akad menghibahkan sesuatu dan menjualnya. Akad-akad yang berlawanan (mutadhadah) inilah yang dilarang dihimpun dalam satu transaksi (Hasanudin, 2009: 24).

\section{HASIL PENELITIAN}

\section{Pelaksanaan Pinjaman dengan Jaminan Emas Mulia di Pegadaian Syariah}

Berdasarkan penelitian skripsi yang ditulis oleh Cut Muliati (Cut Muliati, Skripsi, 2015: th.), dijelaskan bahwa Produk Gadai Syariah MULIA, dilaksanakan dengan akad murabahah, dimana jual beli dilaksanakan dengan pembayaran tangguh, dan emas yang dibeli tidak langsung diterima oleh pembeli, melainkan ditahan oleh pegadaian syariah sebagai penjual dengan akad al-rahn sampai pembayaran dibayar lunas oleh pembeli atau nasabah. Sehingga dalam transaksi MULIA ini menggunakan dua akad yaitu akad murabahah dan akad rahn.

Emas logam mulia yang dibeli tidak diserahkan langsung kepada pihak pembeli (nasabah), melainkan ditahan untuk tetap berada di bawah penguasaan pihak pertama (pegadaian syariah) sebagai jaminan sampai pembayaran angsuran lunas.

Selanjutnya, ketika kontrak sedang berjalan, pihak pegadaian syariah juga memperbolehkan nasabah yang mengambil pembiayaan MULIA untuk mengambil pinjaman dana dengan jaminan emas MULIA yang belum lunan cicilannya tersebut.

Seorang nasabah yang diperbolehkan untuk mengajukan pinjaman dengan menjaminkan emas yang menjadi objek jaminan pada pembiayaan MULIA dengan ketentuan bahwa yang bersangkutan sudah hampir melunasi cicilannya pada pembiayaan MULIA. Maka prosedur yang harus dilakukan oleh nasabah tersebut adalah dengan mengikuti tata cara pelaksanaan gadai yang telah diatur sebagai berikut:

1. Emas yang akan digadaikan harus mempunyai keterangan hak penuh atau hak milik nasabah tersebut.

2. Emas yang dibeli secara non tunai melalui pembiayaan MULIA boleh dijadikan sebagai jaminan produk lain dengan ketentuan pembayaran cicilannya tinggal 2/3 \% lagi (Nurhasita, Skripsi, 2015: t.h.). 


\section{Tinjauan Hukum Islam tentang Pelaksanaan Pinjaman dengan Jaminan Emas pada Pembiayaan MULIA di Pegadaian Syariah}

Manusia dalam memenuhi kebutuhan hidupnya sehari-hari, baik kebutuhan primer, sekunder maupun tersier tidak semuanya dapat terpenuhi, karena tidak memiliki dana yang cukup, sehingga tidak jarang karena tidak ada barang yang dijual, ia terpaksa mencari pinjaman kepada orang lain.

Dengan berkembangnya perekonomian masyarakat yang semakin meningkat, maka seorang dapat mencari uang pinjaman melalui jasa pembiayaan baik melalui lembaga keuangan bank maupun lembaga keuangan non bank, diantaranya adalah Lembaga Pegadaian termasuk juga pegadaian syariah.

Emas yang setianya dijadikan salah satu bentuk jaminan terhadap dana yang disalurkan oleh pegadaian syariah kepada nasabahnya pada produk pembiayaan MULIA, dalam perjalanannya ternyata oleh pihak pegadaian syariah memperbolehkan kembali nasabah untuk mengajukan peminjaman dana yang baru dengan menjaminkan emas yang masih belum lunas cicilannya tersebut.

Dalam ketentuan hukum Islam jaminan bertujuan untuk menjamin keamanan piutang murtahin (penerima gadai) dari tindakan wanprestasi rahin (penggadai). Sebagaimana firman Allah Swt.:

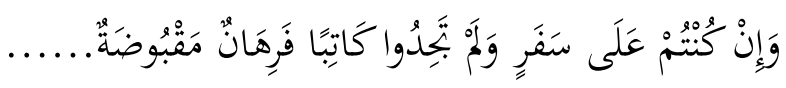

Jika kamu dalam perjalanan (dan bermuamalah tidak secara tunai) sedang kamu tidak memperoleh seorang penulis, maka hendaklah ada barang tanggungan yang dipegang (oleh yang berpiutang)....(Q.S. al-Baqarah [2]: 283)

Dalam ketentuan barang yang dijadikan objek jaminan dijelaskan oleh para ulama figh bahwa (Wahbah azZuhaili, t.th.: t.h.), marhun adalah harta yang ditahan oleh pihak murtahin untuk mendapatkan pemenuhan atau pembayaran haknya yang menjadi marhun bih.

Menurut ulama Hanafiyyah, salah satu syarat yang harus dipenuhi marhunadalah bahwa marhun harus berstatus milik rahin atau milik orang yang berada dalam perwalian rahin atau telah mendapat izin dari pemiliknya untuk digadaikan oleh rahin (Wahbah azZuhaili, t.th: t.h.). Kemudian, sejumlah harta dikatakan menjadi milik seseorang atau dengan kata lain seseorang bisa disebut punya haqq al-'aini (Nasrun Haroen, 2000: 6), jika dia berkuasa penuh atau memiliki kekuasaan untuk menggunakan harta tersebut.

Sementara itu status emas yang dijadikan jaminan pada pembiayaan MULIA tidak bisa dijadikan objek jaminan untuk transaksi pinjaman berikutnya, karena belum bisa dikatakan menjadi milik nasabah sepenuhnya karena emas tersebut belum lunas.

Kemudian, parameter lain untuk bisa menilai suatu produk apakah telah memenuhi prinsip syariah atau tidak adalah dengan memperhatikan akad-akad dan berbagai ketentuannya yang digunakan dalam produk tersebut. Produk-produk dalam kegiatan keuangan syariah, jika terhadapnya dilakukan al-takyif al-figh/ tinjauan fikih, beberapa atau bahkan sebagian terbesar ternyata mengandung beberapa akad.

Sebenarnya ketika terjadi kontrak pembiayaan mulia, telah terjadi dua akad di sana, yaitu akad murabahah ketika 
nasabah membeli emas secara cicilan. Dan akad yang kedua adalah akad rahn ketika nasabah menjadikan emas mulia sebagai jaminan. Tetapi, pada dasarnya ini bukan substansi terjadinya akad berganda yang dilarang, karena pelaksanaan kedua akad tersebut dilegalkan sebagaimana penjelasan hukumnya yang terdapat dalam surat alBaqarah ayat 283.

Namun, yang menjadi pokok persoalan adalah akad utang piutang dengan jaminan emas MULIA yang belum lunas cicilannya. Menurut penulis, akad tersebut merupakan akad berganda yang dilarang dalam hukum Islam. Sebagaimana sabda Rasulullah Saw.:

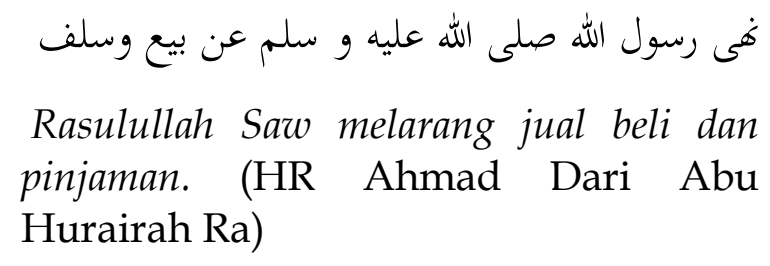

Rasulullah Saw melarang jual beli dan pinjaman. (HR Ahmad Dari Abu Hurairah Ra)

Pada transaksi yang terjadi antara nasabah dengan pihak bank bila merujuk pada larangan Hadis di atas, pembiayaan MULIA sebagai akad pertama itulah jual beli yang dimaksud, kemudian akad salaf (pinjaman) yaitu pada kontrak yang kedua yaitu ketika nasabah menjaminkan kembali emas pada pembiayaan MULIA untuk pinjaman yang diajukan.

Terjadinya akad yang kedua bergantung kepada akad yang pertama atau tidak bisa dilepaskan dari akad yang pertama, karena objek yang dijadikan jaminan untuk akad yang kedua merupakan objek yang dijaminkan pada akad yang pertama yang belum selesai kontraknya. Jadi bisa disimpulkan bahwa akad-akad tersebut terkait satu sama lainnya.

Selanjutnya menurut penulis, di samping adanya larangan yang berlaku pada pinjaman dengan jaminan objek pembiayaan MULIA, adanya larangan akad berganda/multi akad dalam hukum Islam, jika melihat pada pelaksanaan akad di atas, terlihat di sana pihak pegadaian selalu pada posisi yang diuntungkan. Pada pelaksanaan multi akad tersebut pihak pegadaian banyak sekali mendapatkan keuntungan. Pertama pada akad murabahah pihak mendapatkan keuntungan dari margin penjualan emas, kemudian dari biaya pemeliharaan ketika emas itu dijadikan jaminan. Kemudian keuntungan yang lain didapatkan pada pelaksanaan akad yang kedua, ketika emas pada pembiayaan MULIA dijadikan kembali sebagai jaminan. Maka dalam hal ini, pihak pegadaian syariah akan mendapatkan keuntungan kembali dari biaya pemeliharaan jaminan emas. Bahkan yang terjadi adalah terhadap objek jaminan yang sama, berlaku dua kali jaminan secara bersamaan.

Di sisi lain, nasabah dalam hal ini berada pada posisi terzalimi. Karena pada dasarnya orang tidak akan mengajukan pinjaman kecuali pada kondisi membutuhkan, apalagi pada saat yang bersamaan yang bersangkutan masih berutang membayar cicilan pelunasan emas yang dibelinya kepada pegadaian syariah.

\section{PENUTUP}

Dalam rangka memenuhi kebutuhan masyarakat dan mengembangkan industri atau bisnis praktisi telah melakukan berbagai upaya untuk menciptakan produkproduk baru atau bahkan dan ini yang paling banyak melakukan adaptasi dan "syariatisasi" terhadap produk-produk lama (konvensional). Untuk yang terakhir ini, mengingat fungsinya masih relavan dan dan diperlukan, nama produk lama tetap 
dipertahankan, tentu saja dengan diberi label khusus untuk membedakannya dari produk konvensional; misalnya diberi kata "syariah".

Terhadap pelaksanaan pinjaman dengan jaminan emas MULIA yang ada di pegadaian syariah tidak sesuai dengan hukum Islam. hal ini disebabkan karena tidak terpenuhinya syarat yang dijadikan sebagai objek jaminan, dimana syaratnya adalah milik yang sempurna dari orang yang berutang. Di sisi lain, telah terjadi bentuk praktik akad berganda yang dilarang dalam hukum Islam, yaitu menghimpunkan antara akad jual beli dan akad salaf (utang piutang).

\section{DAFTAR KEPUSTAKAAN}

Haroen, Nasrun. 2000. Figh Mu'amalah, Jakarta: Gaya Media Pratama.

Hasanudin. 2009. Multi Akad dalam Transaksi Syariah Kontemporer Pada Lembaga Keuangan Syariah di Indonesia, Ciputat : UIN Syahid.

Karim, Adiwarman, 2004, Bank Islam Analisis Fiqih dan Keuangan, Jakarta: Raja Grafindo Persada

al-Kasani, Imam. t.th. al-Bada'i'u ashShana'i'u, Mesir: al-Muniriyah.
Ma'luf, Louis. 1986. Al-Munjid Fil Lughah, Beirut, Libanon : Darul Masyruq.

Munawwir, Ahmad Warson. 1997. Kamus Al-Munawwir Arab - Indonesia Terlengkap, Surabaya: Pustaka Progresif.

Muliati, Cut, Analisis Teknik Penentuan Margin Pembiayaan Murabahah Logam MULIA Menurut Tinjauan Ekonomi Islam (Studi Kasus pada Pegadaian Syariah Cabang Bireuen),(Skripsi: Prodi Ekonomi Syariah Jurusan Syariah STAIN Malikussaleh Lhokseumawe, 2015)

Nurhasita, Gadai Emas Non Tunai di PT. Pegadaian Syariah Kota Lhokseumawe menurut Ekonomi Syariah, (Skripsi: Prodi Ekonomi Syariah Jurusan Syariah STAIN Malikussaleh Lhokseumawe, 2015)

Qudamah, Ibnu. t.th. al-Mugni, Riyadh: Maktabah ar-Ryadh al-Haditsah,

Rusyd, Ibnu. 1978. Bidayah al-Mujtahid wa Nihayah al-Muqtashid, Beirut: Dar al-Fikr.

Sumitro, Warkum. 2002. Asas-asas Perbankan Islam dan Lembaga-lembaga Terkait, Jakarta: PT. Raja Grafindo Persada.

Tim Penyusun. 1996. Kamus Besar Bahasa Indonesia. Jakarta: Balai Pustaka.

Wahbah az-Zuhaili. t.th. al-Figh al-Islami wa Adillatuhu, Beirut: Dar al-Fikr. 